Review

\title{
COVID-19: A Review of Current Evidence on Phylogenetics and Etiopathogenesis
}

\author{
Rafiq Shajahan and Naganathan K. Pillai \\ Jeffrey Cheah School of Medicine and Health Sciences, Faculty of Medicine, Monash University Malaysia, \\ Jalan Lagoon Selatan, Bandar Sunway, 47500 Subang Jaya, Selangor, Malaysia
}

\author{
Article history \\ Received: 07-10-2020 \\ Revised: 09-01-2021 \\ Accepted: 25-01-2021 \\ Corresponding Author: \\ Rafiq Shajahan \\ Monash University Malaysia, \\ Subang Jaya, Malaysia \\ Email: ohlookitsrafiq@gmail.com
}

\begin{abstract}
COVID-19 represents the latest pandemic caused by the SARSCoV-2 coronavirus. Coronaviruses are RNA viruses that cause a largely viral mediated immune-related syndrome similar to the SARS epidemic. Following metagenomic sequencing, SARS-CoV-2 closely resembles SARS-CoV (79\% similarity) and MERS-CoV virus (50\% similarity). Despite this, clinical observations have found varying degrees of infectivity and pathogenesis amongst these viruses. Phylogenetic origins of SARSCoV-2 have found connections to bats and pangolins as possible zoonotic reservoirs. It enters the host cells via the receptor binding site of the ACE-2 receptor. Upon entering the host cells, cytopathic effects and interruption of respiratory cilia occur with a resultant cascade of pro-inflammatory cytokines and chemokines. Common clinical features of COVID-19 include fever, cough and fatigue. COVID-19 infected patients also present with various gastrointestinal, gustatory, dermatologic, ocular, cardiovascular, neurologic and coagulopathic manifestations. Dyspnea, sore throat, nasal congestion, musculoskeletal pain, headaches and chills were also observed. Emerging data supports that COVID 19 has disproportionately affected specific ethnic groups, particularly racial minorities for various health and institutional reasons. It is estimated around $5 \%$ of all cases are severe, presenting with respiratory failure, shock, acute respiratory syndrome and arrhythmias. Co-infection with other pathogens was also seen with various other viruses such as rhinoviruses, respiratory syncytial virus and other coronaviruses. COVID-19 is able to spread asymptomatically and causes slightly different manifestations in pregnant ladies and the pediatric populations. ARDS in COVID-19 patients is suspected to be a unique clinical entity as lung function testing found high driving pressures with abnormally low lung compliance and low lung recruitability. This requires a unique approach to ventilating COVID-19 ARDS patients. In conclusion, new emerging data will require healthcare professionals to adapt and more studies are required to overcome this critical pandemic.
\end{abstract}

Keywords: COVID-19, SARS-COV2, SARS, MERS-CoV, Pediatrics, Pregnancy, Clotting Factor, Chemokines

\section{Introduction}

Coronavirus disease 2019, better known as COVID-19, has now presented itself as the defining health challenge in modern history. Since the first case of human to human transmission, the infection has caused widespread reverberations to the world's healthcare systems and economy. This novel coronavirus was first recognized in late 2019 (hence COVID-19), as the culprit virus causing small clusters of pneumonia cases in a city within the Hubei Province of China. It was later traced back to a possible zoonotic transmission from a large seafood market dealing with wild animals in Wuhan. In time, the virus rapidly advanced through much of China before quickly appearing in other countries around the world. The World Health Organization (WHO) declared this novel coronavirus a public health emergency of global concern on 30th January 2020 and later coined the virus's new name, "COVID-19" on the 11th of February 2020. By March 11 th 2020, the WHO announced that the COVID-19 outbreak could be characterized as a pandemic. Merely 2 weeks later, on the 24th of March 2020, 
COVID-19 had infected more than 381,000 people across 195 countries (WHO, 2020b).

According to the WHO, as of July 11th 2020, there were approximately 12.3 million confirmed cases worldwide, with 556,335 confirmed deaths, attributed to SARS-CoV 2 virus pandemic. Regions that were highly affected include the Americas, with over $50 \%$ of the world's global caseloads, followed by Europe, South East Asia and the Eastern Mediterranean region (WHO, 2020b). These statistics, although dizzying, may not be truly representative of the situation at hand, however; as these numbers are likely underrepresented due to various factors, such as testing shortages, large reservoirs of asymptomatic cases, lack of effective communication and public stigmatization, which may worsen the pandemic. Despite rapid identification of the virus, its high rate of infectivity and lack of efficacious treatments or vaccines may make elimination of COVID-19 an extremely daunting task (Maqbool and Khan, 2020). We provide a detailed and recent review into the evidence available on the etiopathogenesis and clinical presentation of COVID-19 to better aid clinicians and spur new avenues for high quality studies in the future.

\section{Coronaviruses of the Past and COVID-19}

Coronaviruses, which are mostly composed of a positive single stranded RNA genome, have the ability to be pathogenic in both humans and animals. There are 7 known subtypes of viruses that have an impact on humanity, including the SARS-CoV2 virus, the newly discovered virus responsible for COVID-19. Other coronaviruses, such as Human Coronavirus 229E, NL63, OC43 and HKU1 have previously been shown to cause minor symptoms by exclusively infecting the upper airway (Fehr and Perlman, 2015). However, COVID-19 is different as it constitutes a largely viral-mediated syndrome with a vast multitude of presentations (Cao and $\mathrm{Li}, 2020 \mathrm{a}$ ). New information is constantly emerging as time progresses on.

The novel human coronavirus was initially discovered via metagenomic sequencing and targeted Real-Time Polymerase Chain Reaction (qRT-PCR) from the bronchoalveolar lavage fluid of a patient cluster in Wuhan, China (Zhu et al., 2020). Following that, it was quickly discovered that SARS-CoV-2 belonged to the betacoronavirus genus of the Orthocoronaviridae family, bearing close resemblances to the SARS-CoV (79\% similarity) and MERS-CoV viruses (50\% similarity) (Lu et al., 2020). Other genomic studies have unveiled that the SARS-CoV-2 also shares $88 \%$ similarities of its genome to two distinct bat-derived SARS-like coronaviruses isolated in Eastern China in 2015, namely the bat-SL-CoVZC45 and bat-SL-CoVZXC21 (Lu et al., 2020). Among all coronaviruses, SARS-CoV-2 was recently found to be most similar (98\%) to the $\mathrm{BatCoV}$ RaTG13 virus found in the Intermediate Horseshoe bat,
Rhinolophus affinis from the Yunnan province of China. (Zhou et al., 2020b; Tay et al., 2020).

Despite close genetic similarities, these viruses have different potential to cause widespread disease. For instance, the SARS-CoV-2 has been found to have a far higher potential for pandemics with a reproductive number $\left(R_{0}\right)$ of between 2 and 2.5 as per the WHO. This is higher than that of both the previous SARS (1.7-1.9) and MERS epidemics $(<1)$. Interestingly, a study by Liu reported an average reproductive number of 3.28 for the SARS-CoV-2 virus, but this could be inaccurate due to insufficient data and shorter duration of study in this study (Liu et al., 2020). Differences in social cultures, mitigation strategies and outbreak staging have led to a wide range of values of $\mathrm{R}_{0}$, ranging from 2.2-3.6 to 4.1-6.5 (Kwok et al., 2020). As a solution, proposed the use of a dynamic SusceptibleExposed-Infectious-Recovered (SEIR) epidemiological $R_{0}$ via machine learning to increase the accuracy of values in the future. This method was previously used to aid national policymaking for the HIV epidemic (Linka et al., 2020). Despite the higher infectivity rate, COVID-19 appears to be associated with milder disease when compared to other coronaviruses. Projections of case fatality rates of SARS-CoV-2 hovers around $2.8 \%$ in males and $1.7 \%$ in females, which is lower than the other two mentioned coronaviruses (Novel, 2020). Table 1 below describes key differences between these viruses.

\section{Phylogenesis and Possible Origins}

SARS-CoV-2 has features typical of other betacoronaviruses, namely 14 Open Reading Frames (ORF) encoding for 27 proteins. Viral replication in SARS-CoV-2 stems from 15 non-structural proteins coded from ORF 1 and ORF 2 at the 5 'terminal region of the viral genome (Malik et al., 2020; Petrosillo et al., 2020). The structure of the virus comprises of Spike proteins (S), Envelope protein $(\mathrm{E})$, Membrane protein $(\mathrm{M})$ and Nucleocapsids $(\mathrm{N})$. These proteins originate from the 3 'terminal region of the genome (Wu et al., 2020a; Petrosillo et al., 2020). Cytogenetic studies confirm that there are as little as 380 amino acid substitutions between SARS-CoV-2 and SARS-like coronaviruses. These differences are mostly concentrated in the non-structural proteins and spike protein $\mathrm{S}$ used for cell binding and entry. These findings again make COVID-19 very similar genetically to the SARS-CoV pandemic of 2003 and the bat SARS-like virus that was isolated from Intermediate Horseshoe bats mentioned earlier. These features not only reaffirm a possible wild bat reservoir between these viruses but also provide some insight into the differing virulence and infectivity between SARS-CoV and SARS-CoV-2. Further phylogenetic investigations on 103 strains of SARS-CoV-2 in China show 2 different types of viruses namely type L (responsible for $70 \%$ of infections) and type S (responsible for 30\% of infections) (Tang et al., 2020b; Li et al., 2020b). 
Table 1: Comparisons between features of recent outbreaks

\begin{tabular}{|c|c|c|c|c|c|c|c|}
\hline Disease & $\begin{array}{l}\text { Animal } \\
\text { reservoir }\end{array}$ & $\begin{array}{l}\text { Intermediate } \\
\text { host }\end{array}$ & $\begin{array}{l}\text { Receptor of } \\
\text { interest (Virion- } \\
\text { host cell) }\end{array}$ & $\begin{array}{l}\text { Period of } \\
\text { incubation }\end{array}$ & Total cases & Mortality rate & $R_{0}$ \\
\hline $\begin{array}{l}\text { SARS-CoV-2(COVID } \\
\text {-19) (McGonagle } \text { et al., } \\
\text { 2020; Liu } \text { et al., } \\
\text { 2020; She } \text { et al., 2020) }\end{array}$ & $\begin{array}{l}\text { Possibly } \\
\text { Bats }\end{array}$ & $\begin{array}{l}\text { Possibly } \\
\text { pangolins }\end{array}$ & $\begin{array}{l}\text { Spike protein } \\
\text { to Angiotensin- } \\
\text { converting } \\
\text { enzyme } 2\end{array}$ & 3-18 days & $\begin{array}{l}12.3 \text { million } \\
\text { (as of July } \\
11 \text { th } 2020 \text { ) }\end{array}$ & $\begin{array}{l}3.4 \% \text { as } \\
\text { per WHO }\end{array}$ & $2.5-3.28$ \\
\hline $\begin{array}{l}\text { SARS-CoV (SARS } \\
\text { 2003; Petrosillo et al., } \\
\text { 2020; Li, 2016) }\end{array}$ & Bats & Civet cat & $\begin{array}{l}\text { Spike protein } \\
\text { to Angiotensin } \\
\text { converting enzyme } 2\end{array}$ & 2-7 days & 8,098 & $9.6 \%$ & $1.7-1.9$ \\
\hline $\begin{array}{l}\text { MERS-CoV (MERS } \\
\text { 2012; Cheng et al., } \\
\text { 2004; Li, 2016) }\end{array}$ & Bats & Camels & $\begin{array}{l}\text { Spike protein to } \\
\text { Dipeptidyl Peptidase } \\
4 \text { (DPP4) }\end{array}$ & 5 days & 2,494 & $34 \%$ & $<1$ \\
\hline $\begin{array}{l}\text { H1N1 Influenza a } \\
\text { (1918; 2009; Dou et al., } \\
\text { 2018; Parrish et al., } \\
\text { 2015; Prevention, 2019) }\end{array}$ & $\begin{array}{l}\text { Wild Aquatic } \\
\text { birds }\end{array}$ & $\begin{array}{l}\text { Mainly poultry } \\
\text { but also pigs, } \\
\text { horses and minks }\end{array}$ & $\begin{array}{l}\text { Hemaglutinin to } \\
\text { Sialic acid }\end{array}$ & 1-4 days & $\begin{array}{l}60.8 \text { million in } \\
2009,500 \text { million } \\
\text { in } 1918\end{array}$ & $0.02 \%$ & $1.4-1.7$ \\
\hline
\end{tabular}

The cardinal strain in the initial pandemic was the $\mathrm{L}$ subtype but it became the minor strain when COVID-19 had broadened outside of China. The clinical significance between the two strains remains unclear. Similar viral strains have also been isolated in Pangolins, spurring theories explaining this observation.

Pangolins have been increasingly implicated in the pandemic as more evidence of its association begins to unfold. Liu et al. (2019) initially discovered that pangolin lung samples had contained a similar SARS$\mathrm{CoV}$-like virus. The Pangolin-CoV virus is strikingly similar to both SARS-CoV-2 and BatCoV RaTG13 at 91.02 and $90.55 \%$ respectively, making it the closest related viral genome after the aforementioned $\mathrm{BatCoV}$ RaTG13 virus (Zhang et al., 2020a). Interestingly, upon genomic examination of all 3 viruses, there were 5 key amino acids on the binding site of the SARS-CoV-2 virus that were completely indistinguishable from the Pangolin CoV, while the BatCoV RaTG13 has 4 differing mutations (Zhang et al., 2020a). Coronaviruses such as the SARS-CoV and MERS-CoV have been shown in the past to have other intermediate hosts such as civets and camels and it is expected that SARS-CoV-2 is likely to be similar (Azhar et al., 2014; Guan et al., 2003). This may be especially true considering the first ever COVID-19 patient alarmingly disclosed no contact to the culprit seafood market (Huang et al., 2020).

The evidence for the origins of SARS-CoV-2 is perplexing. Some theories of the possible origin of COVID-19 are incongruent with present genomic data. For instance, it is known that while there are various non-aquatic animals sold at the Huanan Seafood Wholesale Market, no bats were sold there at all (Lu et al., 2020). Furthermore, as early as 1 st of January 2020, it was found that $70 \%$ of cases had already had no exposure to the market, while only $10 \%$ of patients had market exposure ( $\mathrm{Li}$ et al., 2020a). Lastly, when comparing SARS-CoV-2 to the earlier mentioned bat viruses bat-SL-CoVZC45 and bat-SL-CoVZXC21, it was discovered that SARS-CoV-2 was not a direct descendant of those viruses despite being genetically similar. This signifies a truly unclear source (Lu et al., 2020). Some media coverage have suggested a possible human synthetic origin. Andersen et al. (2020) recently published an editorial to the journal NATURE utilising current genomic studies regarding the Receptor Binding Domain (RBD) of the spike protein to offer their perspectives on the origins of the SARS-CoV-2 virus. They concluded that while it is impossible to prove or disprove the exact origin of the virus without further study, the genetic data available had irrefutably shown that SARS-CoV-2 could not have emerged through laboratory manipulation (Andersen et al., 2020). They cited that while SARS-CoV-2 may bind to human ACE2 with high affinity, computational analyses predict that this interaction is not ideal and unlike the ideal binding of RBD sequence in the previous SARS-CoV (Wan et al., 2020). This implies that no reversegenetic mechanism was used from the genomic backbone of any of the available betacoronaviruses to manufacture the current SARS-CoV-2 virus (Cui et al., 2019; Almazán et al., 2014).

\section{COVID-19 Specific Pathogenesis}

Similar to SARS-CoV, SARS-CoV-2 uses Angiotensin-Converting Enzyme 2 (ACE2) as its main receptor. The receptor is widely found on the vascular endothelium, respiratory epithelium, macrophages and alveolar monocytes (Lu et al., 2020). It is also expressed in various cells belonging to various tissues in the heart, kidney and gastrointestinal tracts (Imai et al., 2010). Inoculation of SARS-CoV-2 into the epithelial cells of the human airway induces cytopathic effects and interruption of respiratory cilia. Successful isolation of actively replicating live viruses in the upper respiratory tissues has led to the primary means of diagnosing COVID-19, via throat swab and detection of viral 
subgenomic messenger RNA (sgRNA) (Cao and Li, 2020b). Following active replication and subsequent release, the host cells undergo pyroptosis and releases various damaging molecular proteins such as ATP, nucleic acids and ASC oligomers. These molecules set off a cascade of release off pro-inflammatory cytokines and chemokines such as IL-6, IP-10, MIP1 $\alpha$, MIP1 $\beta$ and MCP1 from adjacent epithelial, endothelial and alveolar cells/macrophages. The resultant chemokines attract monocytes, macrophages and $\mathrm{T}$ cells to the site of infection, that will in turn further reinforce a pro-inflammatory feedback loop (Tay et al., 2020).

The outcome of the disease varies depending on the health of the host's immune system. In patients with a defective immune response, an inappropriate intensification of the pro-inflammatory cascade leads to a collection of immune cells that destroy lung parenchyma. The eventual cytokine storm circulates to cause multi-organ damage and non-neutralising antibodies made by B cells may augment SARS-CoV-2 by way of antibody-dependant-enhancement. In patients with a robust immune system, virus-specific $\mathrm{T}$ cells promptly enter the site of infection, eliminating the virus, while neutralising antibodies produced by B cells will function to block viral replication. Next, circulating macrophages will recognize and engulf these antibody complexes and other apoptotic cells, leading to milder clinical symptomatology. This implies that the combination of the degree of viral burden and host responses predicts the severity of the overall condition (Tay et al., 2020). Another notable feature of SARSCoV-2 that relates to its eventual severity is its propensity for optimal binding to the human ACE2 receptor. In fact, based on receptor affinity analysis, SARS-CoV2 binds to ACE2 more efficaciously compared to the 2003 and 2002 strains of SARS-CoV. This is true among humans, ferrets, cats and other species with consistent receptor homogeneity to humans (Andersen et al., 2020; Petrosillo et al., 2020). The Receptor Binding Domain (RBD) in the spike protein is varied among coronaviruses and it is believed that this feature induces the pathogenicity seen among the different coronaviruses (Wu et al., 2020b). This remains a puzzling feature of COVID-19, as in depth studies have revealed that there are no unique amino acid substitutions present between the Receptor Binding Domain (RBD) of the S protein of SARS-CoV-2 and SARS-CoV (Andersen et al., 2020; Wu et al., 2020a). Mutations do occur 6 loci away at other regions of the RBD that do not bind to the human ACE2 receptor. Presently, the clinical significance of this observation remains unclear (Wu et al., 2020a).

\section{Clinical Presentation and Classification of Disease}

Table 2 compares large studies of clinical characteristics. A systematic review published in Italy on April 13th 2020, during the country's worst weeks of the pandemic, looked into 5 retrospective cohort studies investigating a total of 1,556 patients (Lovato and de Filippis, 2020). The review found that in those affected with COVID-19, $895(57.5 \%)$ patients were males and $661(42.5 \%)$ were females. The median age ranged between 44-57 years among the 5 studies. The top 3 reported symptoms following pooled data analysis were fever (85.6\%), cough (68.7\%) and fatigue $(39.4 \%)$. Upon categorising pre-conditions in these patients, $17.4 \%$ had hypertension while both diabetes and coronary heart disease had each been found in $3.8 \%$ of patients respectively (Lovato and de Filippis, 2020). Symptomatology was also discussed in the WHO-China joint report on COVID-19, which featured 55,924 patients. It was discovered that fever was seen in $85 \%$ of cases, with only $45 \%$ being febrile early on following exposure. Cough was present in $67.7 \%$ of patients, whilst $33.4 \%$ of study patients had sputum production. Other respiratory symptoms such as dyspnea, sore throat and nasal congestion were seen in 18.6, 13.9 and $4.8 \%$ respectively (Organization and Organization, 2020). Emerging data supports that COVID-19 has disproportionately affected specific ethnic groups, particularly racial minorities. This may be explained by the higher rate of underlying health conditions and overall lower socio-economic status. Worst rates within such communities may be due to a larger prevalence of poverty, multigenerational households, essential industry employment, lack of paid sick leave and poor access to healthcare (Shah et al., 2020). It is estimated that around $5 \%$ of all cases are severe and require intensive care treatment. A recent report describing 85 fatal cases of COVID-19 identified that rates for respiratory failure, shock, acute respiratory syndrome and arrhythmia were 94.1, 81.2, 74.1 and 60\% respectively (Du et al., 2020). Patients at highest risk of severe disease and death were patients above the age of 60 years and those with underlying comorbidities (Lovato and de Filippis, 2020, Organization and Organization, 2020). A study examining 1206 patients found that $21 \%$ of patients had co-infection with other pathogens such as rhinoviruses, respiratory syncytial virus and other coronaviruses (Kim et al., 2020). Bacterial and fungal infections were also found to complicate SARS-CoV-2 infections (Zhou et al., 2020a). Table 3 tabulates 2 classification systems proposed to stratify the severity of COVID-19 infections. 
Table 2: Comparison between studies of clinical characteristics

\begin{tabular}{|c|c|c|}
\hline Study & Systematic review (Italy) (Lovato and de Filippis, 2020) & $\begin{array}{l}\text { WHO-China Joint report (China) } \\
\text { (Organization and Organization, 2020) }\end{array}$ \\
\hline Methodology & Pooled data from 5 retrospective cohort study. & $\begin{array}{l}\text { Data collection by } 25 \text { national and } \\
\text { international experts in various } \\
\text { provinces in China. }\end{array}$ \\
\hline Total patients $(\mathrm{n}=)$ & 1,556 & 55,924 \\
\hline $\begin{array}{l}\text { Demographics and } \\
\text { gender }\end{array}$ & $\begin{array}{l}\text { Median age was } 51.8 \text { years. } \\
42.5 \% \text { were female }\end{array}$ & $\begin{array}{l}\text { Median age } 51 \text { years. Majority } \\
(77.8 \%) \text { were aged } 30-69 \text { years old). } \\
77 \% \text { were female. }\end{array}$ \\
\hline Main symptoms & $\begin{array}{l}1 \text { study }(\mathrm{n}=1099) \text { found that } 15.7 \% \text { of cases were } \\
\text { classified as severe. Another study }(\mathrm{n}=140) \text { found } \\
41 \% \text { of severe cases in their cohort } \\
\text { Fever }(85.6 \%) \\
\text { Cough }(68.7 \%) \\
\text { Fatigue }(39.4 \%) \\
\text { Shortness of breath }(21.4 \%) \\
\text { Myalgia/Athralgia }(15.6 \%) \\
\text { Pharyngodynia }(12.4 \%) \\
\text { Headache }(11.4 \%) \\
\text { Nausea and vomiting }(6.8 \%) \\
\text { Nasal congestion }(3.7 \%)\end{array}$ & $\begin{array}{l}\text { Around } 80 \% \text { of patients have mild to } \\
\text { moderate disease while } 13.8 \% \text { have } \\
\text { severe disease (dyspnea, tachypnea, } \\
\text { hypoxia, lung infiltrates) } \\
\text { Fever }(87.9 \%) \\
\text { Dry cough }(67.7 \%) \\
\text { Fatigue }(38.1 \%) \\
\text { Sputum production }(33.4 \%) \\
\text { Shortness of breath }(18.6 \%) \\
\text { Myalgia/Arthralgia }(14.8 \%) \\
\text { Sore throat }(13.9 \%) \\
\text { Headache }(13.6 \%) \\
\text { Chills }(11.4 \%) \\
\text { Nausea or vomiting }(5.0 \%) \\
\text { Nasal congestion }(4.8 \%) \\
\text { Diarrhea }(3.7 \%) \\
\text { Haemoptysis }(0.9 \%) \\
\text { Conjunctival congestion }(0.8 \%)\end{array}$ \\
\hline $\begin{array}{l}\text { Main associated } \\
\text { comorbidities }\end{array}$ & $\begin{array}{l}\text { Hypertension }(17.4 \%) \\
\text { Diabetes }(3.8 \%) \\
\text { Coronary artery disease }(3.8 \%) \\
\text { Abnormal liver function }(2.4 \%) \\
\text { Cerebrovascular disease }(1.7 \%) \\
\text { COPD }(1.4 \%) \\
\text { Cancer }(1.3 \%) \\
\text { Chronic renal disease }(1.0 \%) \\
\text { Immunodeficiency }(0.5 \%)\end{array}$ & Not available \\
\hline Main complications & $\begin{array}{l}\text { Acute respiratory distress syndrome }(6.0 \%) \\
\text { Septic shock }(2.0 \%) \\
\text { Acute kidney injury }(1.0 \%) \\
\text { Death }(2.4 \%) \\
\text { Death }(3.8 \%)\end{array}$ & Not available \\
\hline
\end{tabular}

Table 3: Classifications of disease severity based on NIH and Wu classification

\begin{tabular}{|c|c|c|}
\hline Classifications & National Institute of Health (US) (Health, 2020) & $\begin{array}{l}\text { Wu classification (China) (Wu and } \\
\text { McGoogan, 2020) }\end{array}$ \\
\hline Aymptomatic/Presymptomatic & Positive SARS-CoV-2 testing but without symptoms & N/A \\
\hline Mild illness & $\begin{array}{l}\text { Any signs or symptoms (i.e., fever, cough, sore throat, } \\
\text { malaise, headache, muscle pain) without shortness of } \\
\text { breath, dyspnoea or abnormal chest imaging. }\end{array}$ & $\begin{array}{l}\text { No or mild symptoms (fever, fatigue, } \\
\text { cough and/or less common features of } \\
\text { COVID-19) }\end{array}$ \\
\hline Moderate illness & $\begin{array}{l}\text { Evidence if lower respiratory disease by clinical } \\
\text { assessment or imaging and a saturation of oxygen } \\
\left(\mathrm{SaO}_{2}\right)>93 \% \text { on room air at sea level. }\end{array}$ & N/A \\
\hline Severe illness & $\begin{array}{l}\text { Respiratory frequency }>30 \text { breaths } / \mathrm{min}, \mathrm{SaO}_{2} \leq \\
93 \% \text { on room air at sea level, ratio of arterial } \\
\text { partial pressure of oxygen to fraction of inspired } \\
\text { oxygen }\left(\mathrm{PaO}_{2} / \mathrm{FiO}_{2}\right)<300 \text { or lung infiltrates }>50 \% \text {. }\end{array}$ & $\begin{array}{l}\text { Tachypnoea (respiratory rate }>30 \text { breaths/ } \\
\text { min), hypoxia (oxygen saturation } \leq 93 \% \\
\text { on room air or } \mathrm{PaO}_{2} / \mathrm{FiO}_{2}<300 \mathrm{mmHg} \text { ) } \\
\text { or }>50 \% \text { lung infiltrates on imaging. }\end{array}$ \\
\hline Critical illness & $\begin{array}{l}\text { Evidence of respiratory failure, septic shock and/or } \\
\text { multi-organ dysfunction. }\end{array}$ & $\begin{array}{l}\text { Presenting with respiratory failure, shock } \\
\text { or multi-organ dysfunction }\end{array}$ \\
\hline
\end{tabular}




\section{Uncommon Symptoms and Presentation: Gastrointestinal, Ocular, Neurological, Cardiac, Gustatory, Dermatological}

Apart from respiratory symptoms, $40 \%$ of all COVID-19 patients have gastrointestinal symptoms such as diarrhea, diminished appetite and nausea (Xiao et al., 2020; Liang et al., 2020). ACE2 receptors are also found in the gastrointestinal tract and are expressed 100-fold compared to respiratory organs (Han et al., 2020a). Along with ACE2, serine protease TMPRSS2 is also found in abundance in colonic mucosa as it serves to regulate activation of spike protein cleavage. These features may explain the findings of SARS-CoV2 in the feces and rectal biopsies of positive subjects suffering from diarrheal illness (D'Amico et al., 2020; Lin et al., 2020). Fecal calprotectin have been found in high levels in diarrheal COVID-19 patients, mirroring intestinal inflammation (Effenberger et al., 2020). In fact, a recent study detailing autopsies of 12 COVID-19 patients found a $25 \%$ rate of ischemic enteritis on small bowel biopsy (Wichmann et al., 2020). A retrospective study by (Han et al., 2020a) looked into categorizing 206 patients into 3 groups of patients; patients with digestive symptoms only, patients with respiratory symptoms only and patients with both symptoms to highlight the overall regularity of gastrointestinal symptoms. It was found that $19.4 \%$ of patients experienced diarrhoea as a first symptom, lasting on average 5.4 \pm 3.1 days with frequency of $4.3 \pm 2.2$ bowel movements per day. Patients with digestive symptoms presented later for care and had lower duration between symptom onset and viral clearances compared to those with respiratory symptoms (Han et al., 2020a). Gastrointestinal symptoms therefore should be at the forefront of the minds of clinicians upon assessing patients during this pandemic.

Ocular involvement in the previous SARS epidemic is well established in the literature. It has been shown to directly infect the conjunctiva via droplets or spread via the nasolacrimal duct from an upper respiratory tract infection. Viremia can also result from an infection of the lacrimal glands (Seah and Agrawal, 2020). SARS-CoV-2 may spread via a similar route as (Xia et al., 2020) showed that the virus can be detected from the ocular secretions of COVID-19 positive patients. Recent evidence also indicate that conjunctivitis-free COVID-19 patients can also spread the virus (Xie et al., 2020a). However, direct inoculation from such patients is not evident as (Seah and Agrawal, 2020) demonstrated that there is no viral shedding from the tears of infected patients (Seah et al., 2020). Following various case series, COVID-19 specifically has been shown to produce hyper-reflective lesions at the level of the inner plexiform ganglion cell. In addition, viral induced retinitis and optic neuritis as a result of autoantibody formation have been seen in other coronaviruses (Chen et al., 2020; Navel et al., 2020). Data with larger sample size surrounding ocular manifestations of COVID-19 remains sparse. A retrospective review of 38 patients with COVID-19 found that 12 of the patients had a combination of chemosis, epiphora and conjunctival hyperemia. Features associated with ocular manifestations include presence of severe systemic disease, raised levels of white cell counts, procalcitonin, $\mathrm{C}$-reactive protein and lactate dehydrogenase. The authors remarked that a minimum of 2 positive rT-PCR samples from infected conjunctivas could prove sufficient to transmit the infection, however, more in-depth study into this mechanism is needed (Wu et al., 2020c).

Neurological complications have previously been observed in SARS-CoV and MERS CoV infections (Desforges et al., 2013). Unsurprisingly, there has been an increasing number of patients with COVID-19 displaying neurological symptoms. However, very few studies have investigated the repercussions of COVID19 on the nervous system (Panciani et al., 2020). Diagnostic workup is often onerous as neuroimaging is often inconclusive and lumbar puncture is rarely positive, complicating any meaningful studies (Ye et al., 2020). Mao et al. (2020) produced the earliest report on the neurological manifestations among 214 COVID-19 patients. Of these, 78 (36.4\%) of patients had neurological sequelae. Within those patients, 35 (24.8\%) patients had CNS abnormalities, 23 (13.1\%) patients had musculoskeletal injury while $19(8.9 \%)$ patients had peripheral nervous system abnormalities. Headaches and dizziness were the most common Central Nervous System (CNS) symptoms whereas taste and smell impairment represent the most common Peripheral Nervous System (PNS) symptoms. Nervous system involvement was seen more commonly in severe infections, with cerebrovascular disease, impaired consciousness, ataxia and seizures reported in the literature (Mao et al., 2020). Severe neurological symptoms often succeeded respiratory involvement. A research team in Italy named these patients as "NeuroCOVID" and observed 3 distinct clinical-pathological processes; (1) Cerebral thrombosis with haemorrhagic infarct, (2) demyelinating lesions and (3) encephalopathy (Panciani et al., 2020). They describe that SARS-CoV-2 may spread hematogenously to the brain before interacting with the host cell via the spike protein S1 and ACE2 receptors. This induces direct neuronal damage before eliciting indirect damage via an immune-mediated response in the CNS. The authors generally recommend that prompt active treatment be instituted for these patients, with diagnosis mainly relying on clinical parameters and neuroimaging. Routine CSF examination should not be made mandatory for treatment at this time (Panciani et al., 2020). 
Cardiac injury has also been found in COVID-19 infected patients. A single centre study found that $19 \%$ of patients had cardiac involvement and these patients had a higher overall mortality risk (Shi et al., 2020). Historically, the previous SARS-CoV and MERS-CoV virus caused a multitude of cardiovascular related maladies such as hypotension, arrhythmias, myocarditis, pericarditis and Sudden Cardiac Death (SCD) (Kochi et al., 2020). Persistent sinus tachycardia was also observed during the SARS epidemic with postulated causes including deconditioning, impaired cardio-pulmonary function, thyroid and autonomic dysfunction (Kochi et al., 2020). COVID-19 has been found to similarly affect the myocardial tissue. Patients with severe symptoms had a higher prevalence of cardiac disease such as acute cardiac injury, shock and arrhythmias at 7.2, 8.7 and $16.7 \%$ respectively based on one study (Wang et al., 2020). This often translated to poorer outcomes as cardiac patients required more non-invasive and invasive ventilation with higher rates of death. Another study identified that elevated Troponin $\mathrm{T}$ levels was predictive for mortality by a wide margin (59.6 Vs 8.9\%) (Guo et al., 2020). It is likely that COVID-19 strikes a physiological imbalance by increasing metabolic stress and reducing cardiac supply. This could then be deadly to high risk patients when the exaggerated immune response of COVID-19 sets in (Guo et al., 2020). Clinicians should monitor cardiac biomarkers in all COVID-19 patients to increase the likelihood of earlier diagnosis and prompt intervention. The possible utilisation of cardiac magnetic resonance might identify patients who developed cardiac injury in the post infective stage.

The occurrence of olfactory and gustatory dysfunctions are common features of viral infections. Inflammatory reactions of the nasal mucosa may induce rhinorrhea and congestion especially with common viruses such as rhinovirus, parainfluenza and EpsteinBarr virus (Suzuki et al., 2007). A multicentered European study conducted in Belgium studied a total of 417 mild to moderate COVID-19 patients and found that 85.6 and $88 \%$ of patients had significant olfactory and gustatory dysfunctions respectively (Lechien et al., 2020). Facial pain and nasal obstruction were specifically the most common symptoms. More women were affected $(63.1 \%)$ in the study population. The study also showed that $79.6 \%$ of these patients were anosmic while $20.4 \%$ were hyposmic (Lechien et al., 2020). Crucially, among the $18.2 \%$ of patients without nasal symptoms, $79.7 \%$ were recognized to be either hyposmic or anosmic instigating the author's recommendation of having a high index of suspicion for COVID-19 in patients with sudden onset anosmia or ageusia (Lechien et al., 2020).
Skin manifestations in COVID-19 has since proven diverse based on published literature. A preliminary review of inpatient COVID-19 patients in Italy found an estimated $20.4 \%$ of 88 patients developed cutaneous manifestations that included erythematous rashes (14 patients), widespread urticaria (3 patients) and one patient with varicella-like vesicles (Recalcati, 2020). Later, smaller scale studies also found cases of vasculitic skin disease and urticarial diseases (Bouaziz et al., 2020; Henry et al., 2020). Muticentered case series have identified varicella-like exanthems in 22 patients (Marzano et al., 2020). Other dermatological presentations include dengue-like rash, dusky acrocyanosis, dry gangrene, livedo reticularis in various other small studies (Manalo et al., 2020). The prevalence of skin damage related to Personal Protective Equipment (PPE) was cited as high as 97\% as per (Lan et al., 2020) $(\mathrm{n}=542)$. The nasal bridge was the most affected body region $(83.1 \%)$ and goggles were highly implicated (Lan et al., 2020). Incidence of hand dermatitis increased with frequent hand washing. It is estimated that two thirds of healthcare workers will have likely washed their hands over 10 times daily with the advent of the pandemic but only $22 \%$ are applying skin protecting topicals indicating the need for increased skin care education (Darlenski and Tsankov, 2020).

\section{Special Patient Population: The Asymptomatic, Pregnant Women and Children}

There is mounting evidence that pre-symptomatic carriers may be a driving factor of the current pandemic. This may be due to the fact that SARS-CoV-2 has a higher level of virus shedding in the upper respiratory tract compared to its predecessors (Cheng et al., 2004; Gandhi et al., 2020; Wölfel et al., 2020). This feature is seen even in asymptomatic cases and discerns it from SARS-CoV, where replication is observed to occur primarily in the lower respiratory tract, making it possibly less contagious (Cheng et al., 2004; Wölfel et al., 2020). Intriguingly, posterior pharynx saliva samples and serum antibody responses of 23 patients found that unlike SARS, COVID-19 infected patients had the highest viral load near symptom presentation (To et al., 2020). In 1 patient, viral RNA was detected 25 days after symptom onset and 16 patients had positive serum samples 14 days or longer. It was found that older patients related to a higher viral load with the median age being 62 years (To et al., 2020). In January 2020, a familial cluster of 5 patients with fever and respiratory symptoms originating from an asymptomatic family member (patient 1) who travelled from Wuhan, China were studied (Chan et al., 2020). This observation was 
interesting as Patient 1 who had travelled to Wuhan had no symptoms, normal CRP, normal lymphocyte counts and normal CT images. However, other members had raised CRP (ranging 10.1-217 mg/L) and lymphopenia $\left(0.46\right.$ to $\left.0.9 \times 10^{9} / \mathrm{L}\right)$, indicative of the infection. Patient 1 's first rT-PCR swab was a false negative before a second one confirmed the infection. It was later thought to be due to poor quality testing kits (Chan et al., 2020). Another report by (Arons et al., 2020) surveyed an outbreak in a nursing facility in Washington state, USA. Among 76 residents, 56\% were pre-symptomatic, initially testing rRT-PCR positive before eventually developing symptoms 4 days later on average (Arons et al., 2020). Quantitative SARS-CoV-2 viral loads were high regardless of symptoms and viable virus cultures were found in $71 \%$ of the asymptomatic group of patients as well, leading to the conclusion of an increased asymptomatic spread of the virus.

Studies into the pediatric and maternal population remain scarce. The Centers for Disease Control (CDC) received reports regarding 326,335 COVID-19 infected women of whom 8,207 (9\%) were confirmed pregnant. The review concluded that rates of cough and shortness of breath did not differ regardless of pregnancy status but pregnant women reported lower incidences of headache, muscle ache, fevers, chills and diarrhea. Pregnant women were also more likely to be admitted to ICU and require mechanical ventilation. However, rates of death did not differ compared to non-pregnant women (Ellington et al., 2020). A systematic review published recently identified that only $67.4 \%$ of 92 pregnant women presented with symptoms. No women died in these studies with only one needing intensive care and ventilation. Poor neonatal outcomes were recorded including prematurity $(63.8 \%)$, fetal distress $(61.1 \%)$, neonatal ICU admission (42.8\%) and low birth weight (42.8\%) (Smith et al., 2020). Following limited data, possible vertical transmission could occur as there was one pregnant woman documented to have a positive vaginal swab (Kirtsman et al., 2020). This patient's baby was delivered at 35 weeks via caesarean section. The child had 3 positive nasopharyngeal swabs, positive neonatal plasma and stool samples despite strict infection control practices. However, the clinical significance of this singular occurrence remains unclear (Kirtsman et al., 2020). The SARS-CoV-2 detection in breast milk has been conflicting as many studies have mixed results, thus complicating advice to COVID-19 infected mothers (Kirtsman et al., 2020). Hence, expressed breast feeding by another caregiver is recommended in the event of an infected COVID-19 mother (WHO, 2020a).
Children are less afflicted by COVID-19 compared to adults. Children represent approximately 1 to $5 \%$ of all recorded cases. Most cases of pediatric COVID-19 cases are from an adult index case while some were reported as a result of healthcare associated outbreaks (Posfay-Barbe et al., 2020; Schwierzeck et al., 2020). Family clustering has been shown to be responsible for $56 \%$ of infected children (She et al., 2020). A study by (Dong et al., 2020) found that around 4\% confirmed cases were asymptomatic. Among the infected, only 5\% of children had severe disease presenting with dyspnea or hypoxemia with the vast majority of cases having very minimal symptoms. Severe disease occurred more commonly in children who were younger, had underlying pulmonary pathology or were immunecompromised (Ogimi et al., 2019). An editorial by (Cruz and Zeichner, 2020) proposed that children may play an extensive role in community based transmissions as available data suggest that children have an increased upper respiratory tract involvement with prolonged viral shedding, higher rates of asymptomatic cases and an elongated timespan of fecal shedding (Jiehao et al., 2020).

\section{Specific Complications: ARDS}

The SARS-CoV-2 pandemic has initiated new research into the fundamental pathophysiology of Acute Respiratory Distress Syndrome (ARDS). The first ever single-centered study investigating lung recruitability in mechanically ventilated COVID-19 ARDS patients in Wuhan found features different from typical ARDS such as (Pan et al., 2020):

1) No patients had complete airway closure or auto-PEEP

2) Driving pressures were high with abnormally low lung compliance

3) Despite high PEEP, lung recruitability remained low with some changes upon alternating body positions

It is well established that ARDS will present with varying degrees of available aerated lung tissue due to the irregular nature of inflammation, consolidation, flooding and atelectasis typical of the condition (Sahetya et al., 2017). Setting tidal Volumes $\left(V_{T}\right)$ would therefore need to be specific to each patient's respiratory reserves. The Berlin definition for ARDS though widely used, does not provide additive information regarding airway management such as alveolar ventilation, derived from the pulmonary dead space (Nuckton et al., 2002). Some features of COVID-19 ARDS are consistent with other forms of ARDS, particularly hypercapnia in the presence of low $V_{T}$ ventilation. However, some authors have 
stated that while COVID -19 ARDS meets the criteria for Berlin definition of ARDS, COVID-19 may produce a deviant form of the syndrome. A review of 16 ventilated patients delineate that while being in severe hypoxemia, the study patients had a respiratory system compliance of $50.2 \pm 14.3 \mathrm{~mL} / \mathrm{cmH}_{2} \mathrm{O}$ and was associated with a shunt fraction of $0.50 \pm 0.11$ (Gattinoni et al., 2020b). This exhibits an abnormally high lung compliance (indicating preserved lung gas volume) occurring with severe hypoxemia. This feature is inconsistent with the expectation of typical severe ARDS which is of faulty lung recruitment and low lung gas volume due to inflammation. The authors explain that this could be due to hypoxic vasoconstriction and loss of lung perfusion regulation. Patients often have very poor imaging findings and hypoxemia but with paucity of symptoms, i.e., "silent hypoxemia" (Gattinoni et al., 2020b).

Gattinoni et al. (2020a) describes the different subtypes of pneumonia and ARDS in COVID-19. They
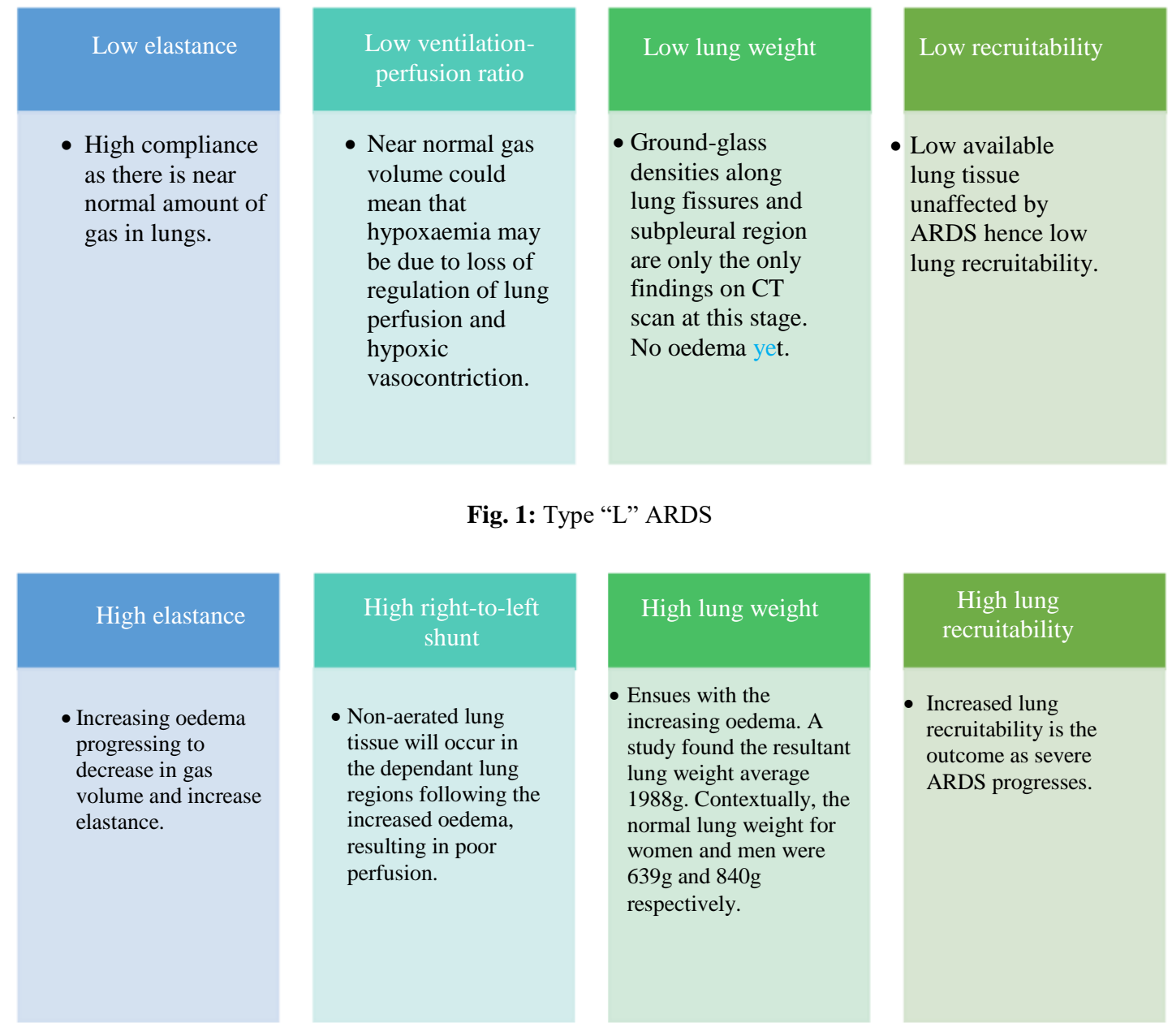

Fig. 1: Type "L" ARDS

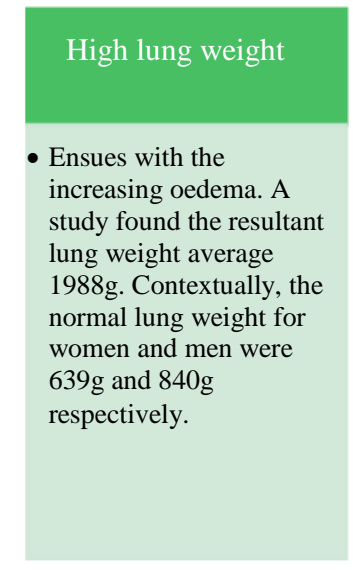

- Ground-glass densities along lung fissures and subpleural region are only the only findings on $\mathrm{CT}$ scan at this stage. No oedema yet.

Fig. 2: Type "H" ARDS
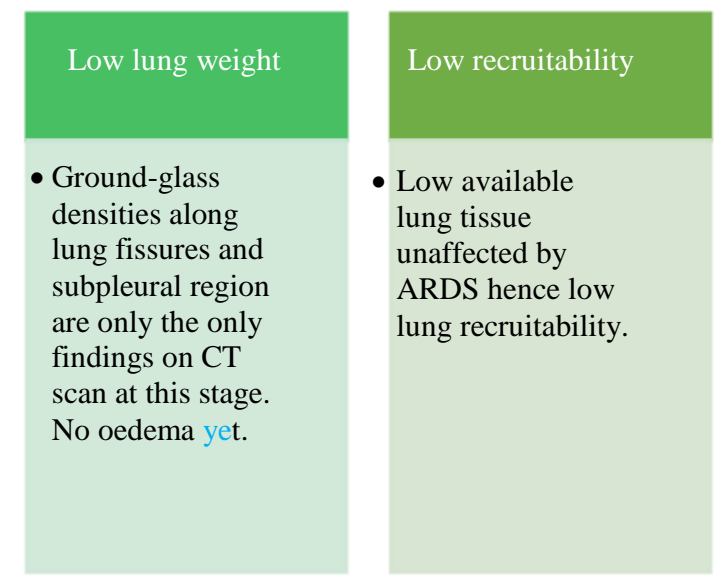

chronicle two main types of COVID-19 lung injuries, namely type $\mathrm{L}$ and type $\mathrm{H}$ described here in Figs. 1 and 2. VID-19 pneumonia initially presents itself with Type

The viral infection leads to local subpleural interstitial oedema that quickly builds over time, increasing the weight of the lung. The depth of negative trathoracic pressure and increased lung permeability occur. This will then reduce the available Total v $\left(\mathrm{T}_{\mathrm{V}}\right)$ for a given inspiratory pressure leading to clinically evident dyspnea. The evolution of disease has been quoted occur due to COVID-19 alone but also sometimes seen patients (Gattinoni et al., 2020a; Wichmann et al., 2020; Molina and DiMaio, 2012; 2015).

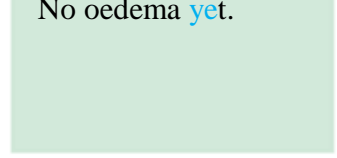

recruitability is outcome as severe ARDS progresses 


\section{Coagulopathy and COVID-19: The Evidence}

COVID-19 has shown to be associated with features of coagulopathy along with its pro-inflammatory condition. Erratic associations between COVID-19 and thromboembolism such as strokes and acute pulmonary embolism have been reported (Xie et al., 2020b). Large vessel strokes in 5 young patients with COVID-19 had been documented in hospitals around New York City (Oxley et al., 2020). A previous study found that the approximate incidence of COVID-19 associated stokes in Wuhan, China was approximately 5\% (Li et al., 2020c). An increased risk of Disseminated Intravascular Coagulopathy (DIC) also occurs with the SARS-CoV-2 virus (Tang et al., 2020a). A case series of 3 patients in Wuhan details patients with severe arterial and venous thrombotic complications. Findings such as bilateral lower limb ischemia, ischemia of several digits of the hand and global regions of cerebral infarcts have been reported (Zhang et al., 2020b). One retrospective review found that as many of $50 \%$ of patients of COVID-19 may have some degree of coagulopathy, providing index of suspicion that COVID-19 itself could truly be the culprit of these thrombotic complications (Zhou et al., 2020a).

Interesting hematological laboratory findings have been documented in COVID-19 patients. Besides recording raised Lactate Dehydrogenase, Ferritin, Creactive protein and Interleukins, COVID-19 patients also have raised D-Dimers (Han et al., 2020b; Casey et al., 2020). A study in particular found that D-Dimer levels greater than $1000 \mu \mathrm{g} / \mathrm{L}$ were particularly associated with mortality (Effenberger et al., 2020). Other revealing lab findings include leucocytosis, thrombocytopenia, prolonged coagulations and elevated fibrinogen. The patients in the previous case series were found to have anti-cardiolipin IgA antibodies, anti- $\beta 2$-glycoprotein 1 IgA and IgG antibodies (Zhang et al., 2020b). These antibodies form the central pathology of AntiPhospholipid Syndrome and its clinical significance to the novel coronavirus requires more research. Autopsies have been carried out to further describe the nature of thromboembolism in COVID-19 patients.

A team of researchers inspected 14 lung autopsy specimens; 7 specimens obtained from patients who died of Influenza A (H1N1) infection and 7 lung specimens of patients who died from COVID-19 (Ackermann et al., 2020). Both lung tissue groups exhibited a common morphological pattern of diffuse alveolar damage, increased perivascular lymphocytes and signs of thrombosis. However, patients with COVID-19 infected lung tissue showed increased severe unexpected endothelial injury, widespread vascular thrombosis, occlusion of alveolar capillaries and vessel growth via intussusceptive angiogenesis (McGonagle et al., 2020; Ackermann et al., 2020; Wichmann et al., 2020). These angiocentric observations in the COVID-19 samples seemed to increase significantly with prolonged hospitalizations and were not seen in the Influenza lung samples (Ackermann et al., 2020). The authors ascribed the quantitative increase in intussesceptive angiogenesis and the up-regulation of angiogenesis-associated genes as being specific to COVID-19 (Ackermann et al., 2020). However, important limitations such as small sample size and the differences in time lapse from onset injury (i.e., temporal heterogeneity) between all lung samples make the relevance of the findings unclear, especially with ARDS patients. Furthermore, none of the COVID-19 patients were intubated whereas nearly all patients with influenza were intubated and ventilated in settings not known to be lung protective (Hariri and Hardin, 2020).

Next, a detailed prospective study in Germany involved performing autopsies on 12 consecutive COVID-19 positive deaths (Wichmann et al., 2020). The finding of the autopsies were further corroborated with post-mortem CT's, histopathological specimen examinations and virology analysis. The patient group included a median age of 73 years, a male preponderance of $75 \%$ and Coronary Heart Disease, Asthma and COPD being the most commonly encountered comorbidity. There was a relatively high incidence of deep venous thrombosis $(58 \%)$ with approximately one third of patients succumbing to a pulmonary embolism. SARSCoV-2 RNA was detected in all the lung samples with evidence of viremia in 6 patients and high viral RNA in liver, kidney and heart in 5 patients.

It is well established that the coagulation cascade in the body is often triggered by various other viruses such as dengue, HIV and the Ebola viruses. This is in part due to the imbalances of pro-coagulant and anticoagulant responses that can commonly accompany viral infections (Subramaniam and Scharrer, 2018). Pathogenic mechanisms that likely occur include endothelial dysfunction, increasing von-Willebrand factors, Toll-like receptor activation and tissue factor pathway activation (Giannis et al., 2020). Interestingly, platelet in themselves are pivotal arbiters of inflammation, having the ability to sense antigens via cell surface receptors and interact with the players of the cellular and humeral immunity. Indeed, these interactions result in a rich network of activated macrophages, monocytes, endothelial cells and lymphocytes with the sum of their interactions leading to a spectrum of pro-coagulant or anti-coagulant states against viral infection (Van Gorp et al., 1999). These features are supported by the work of (Tang et al., 2020a) reporting Disseminated Intravascular Coagulopathy (DIC) in $71.4 \%$ of non-survivors and $0.6 \%$ of survivors of COVID-19 patients. 


\section{Conclusion}

The knowledge on COVID-19 is ever evolving. Pivotal questions still remain unanswered regarding populations at risk, methods of transmission and management among others. More enlightening research is needed. Detailed analysis into the epidemiology, characteristics and complications can provide clinicians the tools necessary for early identification and management of especially high risk cases. It is no doubt that the ensuing months ahead from COVID-19 will pose the greatest challenge clinicians have faced in a generation. However, with more in depth study into the inner workings of COVID-19, healthcare workers will most certainly be able to construct a viable treatment plan for the long term.

\section{Acknowledgement}

We would like to express our special thanks for Monash University of Malaysia for the expertise rendered for the completion of this manuscript.

\section{Author's Contributions}

Rafiq Shajahan: Critically appraised and reviewed papers required to produce this manuscript. He drafted, completed, rearranged and developed this manuscript to its publication.

Naganathan K. Pillai: Conceived the idea for this manuscript and facilitated in preparing, refining and proofreading the manuscript. He acts as the supervisor for this manuscript.

\section{Ethics and Conflict of Interest}

The Authors foresee no ethical issues that may arise after the publication of this manuscript. We declare no conflicts of interest.

\section{References}

Ackermann, M., Verleden, S. E., Kuehnel, M., Haverich, A., Welte, T., Laenger, F., ... \& Jonigk, D. (2020). Pulmonary vascular endothelialitis, thrombosis and angiogenesis in Covid-19. New England Journal of Medicine, 383(2), 120-128. https://doi.org/10.1056/NEJMoa2015432

Almazán, F., Sola, I., Zuñiga, S., Marquez-Jurado, S., Morales, L., Becares, M., \& Enjuanes, L. (2014). Coronavirus reverse genetic systems: infectious clones and replicons. Virus research, 189, 262-270. https://doi.org/10.1016/j.virusres.2014.05.026

Andersen, K. G., Rambaut, A., Lipkin, W. I., Holmes, E. C., \& Garry, R. F. (2020). The proximal origin of SARS-CoV-2. Nature medicine, 26(4), 450-452. https://doi.org/10.1038/s41591-020-0820-9
Arons, M. M., Hatfield, K. M., Reddy, S. C., Kimball, A., James, A., Jacobs, J. R., ... \& Jernigan, J. A. (2020). Presymptomatic SARS-CoV-2 infections and transmission in a skilled nursing facility. New England journal of medicine, 382(22), 2081-2090. https://doi.org/10.1056/NEJMoa2008457

Azhar, E. I., El-Kafrawy, S. A., Farraj, S. A., Hassan, A. M., Al-Saeed, M. S., Hashem, A. M., \& Madani, T. A. (2014). Evidence for camel-to-human transmission of MERS coronavirus. New England Journal of Medicine, 370(26), 2499-2505. https://doi.org/10.1056/NEJMoa1401505

Bouaziz, J. D., Duong, T. A., Jachiet, M., Velter, C., Lestang, P., Cassius, C., ... \& Rybojad, M. (2020). Vascular skin symptoms in COVID-19: a french observational study. Journal of the European Academy of Dermatology and Venereology, 34(9), e451-e452. https://doi.org/10.1111/jdv.16544

Cao, W., \& Li, T. (2020a). COVID-19: towards understanding of pathogenesis. Cell Research, 30(5), 367-369. https://doi.org/10.1038/s41422020-0327-4

Cao, W., \& Li, T. (2020b). COVID-19: towards understanding of pathogenesis. Cell Research, 30(5), 367-369. https://doi.org/10.1038/s41422020-0327-4

Casey, K., Iteen, A., Nicolini, R., \& Auten, J. (2020). COVID-19 pneumonia with hemoptysis: acute segmental pulmonary emboli associated with novel coronavirus infection. The American journal of emergency medicine, 38(7), 1544-e1. https://doi.org/10.1016/j.ajem.2020.04.011

Chan, J. F. W., Yuan, S., Kok, K. H., To, K. K. W., Chu, H., Yang, J., ... \& Yuen, K. Y. (2020). A familial cluster of pneumonia associated with the 2019 novel coronavirus indicating person-to-person transmission: a study of a family cluster. The lancet, 395(10223), 514-523. https://doi.org/10.1016/S0140-6736(20)30154-9

Chen, L., Liu, M., Zhang, Z., Qiao, K., Huang, T., Chen, M., ... \& Wang, J. (2020). Ocular manifestations of a hospitalised patient with confirmed 2019 novel coronavirus disease. British Journal of Ophthalmology, 104(6), 748-751. https://doi.org/10.1136/bjophthalmol-2020-316304

Cheng, P. K., Wong, D. A., Tong, L. K., Ip, S. M., Lo, A. C., Lau, C. S., ... \& Lim, W. W. (2004). Viral shedding patterns of coronavirus in patients with probable severe acute respiratory syndrome. The Lancet, 363(9422), 1699-1700. https://doi.org/10.1016/S0140-6736(04)16255-7

Cruz, A. T., \& Zeichner, S. L. (2020). COVID-19 in children: initial characterization of the pediatric disease. Pediatrics, 145(6). https://doi.org/10.1542/peds.2020-0834 
Cui, J., Li, F., \& Shi, Z. L. (2019). Origin and evolution of pathogenic coronaviruses. Nature Reviews Microbiology, 17(3), 181-192. https://doi.org/10.1038/s41579-018-0118-9

D’Amico, F., Baumgart, D. C., Danese, S., \& PeyrinBiroulet, L. (2020). Diarrhea during COVID-19 infection: pathogenesis, epidemiology, prevention and management. Clinical Gastroenterology and Hepatology. https://doi.org/10.1016/j.cgh.2020.04.001

Darlenski, R., \& Tsankov, N. (2020). COVID-19 pandemic and the skin: what should dermatologists know?. Clinics in Dermatology, 38(6), 785-787. https://doi.org/10.1016/j.clindermatol.2020.03.012

Desforges, M., Favreau, D. J., Brison, É., Desjardins, J., Meessen-Pinard, M., Jacomy, H., \& Talbot, P. J. (2013). Human coronaviruses: respiratory pathogens revisited as infectious neuroinvasive, neurotropic and neurovirulent agents. https://doi.org/10.1201/b13908-6

Dong, Y., Mo, X., Hu, Y., Qi, X., Jiang, F., Jiang, Z., \& Tong, S. (2020). Epidemiology of COVID-19 among children in China. Pediatrics, 145(6). https://doi.org/10.1542/peds.2020-0702

Dou, D., Revol, R., Östbye, H., Wang, H., \& Daniels, R. (2018). Influenza A virus cell entry, replication, virion assembly and movement. Frontiers in immunology, 9, 1581. https://doi.org/10.3389/fimmu.2018.01581

Du, Y., Tu, L., Zhu, P., Mu, M., Wang, R., Yang, P., ... $\& \mathrm{Xu}$, G. (2020). Clinical features of 85 fatal cases of COVID-19 from Wuhan. A retrospective observational study. American journal of respiratory and critical care medicine, 201(11), 1372-1379. https://doi.org/10.1164/rccm.202003-0543OC

Effenberger, M., Grabherr, F., Mayr, L., Schwaerzler, J., Nairz, M., Seifert, M., ... \& Tilg, H. (2020). Faecal calprotectin indicates intestinal inflammation in COVID-19. Gut, 69(8), 1543-1544. https://doi.org/10.1136/gutjnl-2020-321388

Ellington, S., Strid, P., Tong, V. T., Woodworth, K., Galang, R. R., Zambrano, L. D., ... \& Gilboa, S. M. (2020). Characteristics of women of reproductive age with laboratory-confirmed SARS-CoV-2 infection by pregnancy status-United States, January 22-June 7, 2020. Morbidity and Mortality Weekly Report, 69(25), 769. https://doi.org/10.15585/mmwr.mm6925a1

Fehr, A. R., \& Perlman, S. (2015). Coronaviruses: an overview of their replication and pathogenesis. Coronaviruses, 1-23. https://doi.org/10.1007/978-14939-2438-7_1

Gandhi, M., Yokoe, D. S., \& Havlir, D. V. (2020). Asymptomatic transmission, the Achilles' heel of current strategies to control Covid-19. https://doi.org/10.4324/9781003141402-4
Gattinoni, L., Chiumello, D., Caironi, P., Busana, M., Romitti, F., Brazzi, L., \& Camporota, L. (2020a). COVID-19 pneumonia: different respiratory treatments for different phenotypes? https://doi.org/10.1007/s00134-020-06033-2

Gattinoni, L., Coppola, S., Cressoni, M., Busana, M., Rossi, S., \& Chiumello, D. (2020b). COVID-19 does not lead to a "typical" acute respiratory distress syndrome. American journal of respiratory and critical care medicine, 201(10), 1299-1300. https://doi.org/10.1164/rccm.202003-0817LE

Giannis, D., Ziogas, I. A., \& Gianni, P. (2020). Coagulation disorders in coronavirus infected patients: COVID-19, SARS-CoV-1, MERS-CoV and lessons from the past. Journal of Clinical Virology, 127, 104362. https://doi.org/10.1016/j.jcv.2020.104362

Guan, Y., Zheng, B. J., He, Y. Q., Liu, X. L., Zhuang, Z. X., Cheung, C. L., ... \& Poon, L. L. M. (2003). Isolation and characterization of viruses related to the SARS coronavirus from animals in southern China. Science, 302(5643), 276-278. https://doi.org/10.1126/science.1087139

Guo, T., Fan, Y., Chen, M., Wu, X., Zhang, L., He, T., ... \& Lu, Z. (2020). Cardiovascular implications of fatal outcomes of patients with coronavirus disease 2019 (COVID-19). JAMA cardiology, 5(7), 811-818. https://doi.org/10.1001/jamacardio.2020.1017

Han, C., Duan, C., Zhang, S., Spiegel, B., Shi, H., Wang, W., ... \& Hou, X. (2020a). Digestive symptoms in COVID-19 patients with mild disease severity: clinical presentation, stool viral RNA testing and outcomes. The American journal of gastroenterology. https://doi.org/10.14309/ajg.0000000000000664

Han, H., Yang, L., Liu, R., Liu, F., Wu, K. L., Li, J., ... \& Zhu, C. L. (2020b). Prominent changes in blood coagulation of patients with SARS-CoV-2 infection. Clinical Chemistry and Laboratory Medicine (CCLM), 1(ahead-of-print). https://doi.org/10.1515/cclm-2020-0188

Hariri, L., \& Hardin, C. C. (2020). Covid-19, angiogenesis and ARDS endotypes. https://doi.org/10.1056/NEJMe2018629

Health, N. I. O. 2020. Overview of COVID-19 [Online]. United States of America. Available: https://files.covid19treatmentguidelines.nih.gov /guidelines/section/section_43.pdf [Accessed 21 June 2020]

Henry, D., Ackerman, M., Sancelme, E., Finon, A., \& Esteve, E. (2020). Urticarial eruption in COVID-19 infection. Journal of the European Academy of Dermatology and Venereology, 34(6), e244-e245. https://doi.org/10.1111/jdv.16472 
Huang, C., Wang, Y., Li, X., Ren, L., Zhao, J., Hu, Y., ... \& Cao, B. (2020). Clinical features of patients infected with 2019 novel coronavirus in Wuhan, China. The lancet, 395(10223), 497-506. https://doi.org/10.1016/S0140-6736(20)30183-5

Imai, Y., Kuba, K., Ohto-Nakanishi, T., \& Penninger, J. M. (2010). Angiotensin-converting enzyme 2 (ACE2) in disease pathogenesis. Circulation Journal, 74(3), 405-410. https://doi.org/10.1253/circj.CJ-10-0045

Jiehao, C., Jin, X., Daojiong, L., Zhi, Y., Lei, X., Zhenghai, Q., ... \& Mei, Z. (2020). A case series of children with 2019 novel coronavirus infection: clinical and epidemiological features. Clinical Infectious Diseases, 71(6), 1547-1551. https://doi.org/10.1093/cid/ciaa198

Kim, D., Quinn, J., Pinsky, B., Shah, N. H., \& Brown, I. (2020). Rates of co-infection between SARS-CoV-2 and other respiratory pathogens. Jama, 323(20), 2085-2086. https://doi.org/10.1001/jama.2020.6266

Kirtsman, M., Diambomba, Y., Poutanen, S. M., Malinowski, A. K., Vlachodimitropoulou, E., Parks, W. T., ... \& Shah, P. S. (2020). Probable congenital SARS-CoV-2 infection in a neonate born to a woman with active SARS-CoV-2 infection. Cmaj, 192(24), E647-E650. https://doi.org/10.1503/cmaj.200821

Kochi, A. N., Tagliari, A. P., Forleo, G. B., Fassini, G. M., \& Tondo, C. (2020). Cardiac and arrhythmic complications in patients with COVID-19. Journal of cardiovascular electrophysiology, 31(5), 1003-1008. https://doi.org/10.1111/jce.14479

Kwok, K. O., Lai, F., Wei, W. I., Wong, S. Y. S., \& Tang, J. W. (2020). Herd immunity-estimating the level required to halt the COVID-19 epidemics in affected countries. Journal of Infection, 80(6), e32-e33. https://doi.org/10.1016/j.jinf.2020.03.027

Lan, J., Song, Z., Miao, X., Li, H., Li, Y., Dong, L., ... \& Tao, J. (2020). Skin damage among health care workers managing coronavirus disease-2019. Journal of the American Academy of Dermatology, 82(5), 1215-1216. https://doi.org/10.1016/j.jaad.2020.03.014

Lechien, J. R., Chiesa-Estomba, C. M., De Siati, D. R., Horoi, M., Le Bon, S. D., Rodriguez, A., ... \& Saussez, S. (2020). Olfactory and gustatory dysfunctions as a clinical presentation of mild-to-moderate forms of the coronavirus disease (COVID-19): a multicenter European study. European Archives of Oto-RhinoLaryngology, 277(8), 2251-2261. https://doi.org/10.1007/s00405-020-05965-1

Li, F. (2016). Structure, function and evolution of coronavirus spike proteins. Annual review of virology, 3, 237-261. https://doi.org/10.1146/annurev-virology-110615042301
Li, Q., Guan, X., Wu, P., Wang, X., Zhou, L., Tong, Y., ... \& Feng, Z. (2020a). Early transmission dynamics in Wuhan, China, of novel coronavirus-infected pneumonia. New England journal of medicine.

Li, X., Geng, M., Peng, Y., Meng, L., \& Lu, S. (2020b). Molecular immune pathogenesis and diagnosis of COVID-19. Journal of pharmaceutical analysis, $10(2)$, https://doi.org/10.1016/j.jpha.2020.03.001

Li, Y., Li, M., Wang, M., Zhou, Y., Chang, J., Xian, Y., ... \& Hu, B. (2020c). Acute cerebrovascular disease following COVID-19: a single center, retrospective, observational study. Stroke and vascular neurology, 5(3). https://doi.org/10.1136/svn-2020-000431

Liang, W., Feng, Z., Rao, S., Xiao, C., Xue, X., Lin, Z., .. \& Qi, W. (2020). Diarrhoea may be underestimated: a missing link in 2019 novel coronavirus. Gut, 69(6), 1141-1143. https://doi.org/10.1136/gutjnl-2020-320832

Lin, L., Jiang, X., Zhang, Z., Huang, S., Zhang, Z., Fang, Z., ... \& Shan, H. (2020). Gastrointestinal symptoms of 95 cases with SARS-CoV-2 infection. Gut, 69(6), 997-1001. https://doi.org/10.1136/gutjnl-2020-321013

Linka, K., Peirlinck, M., \& Kuhl, E. (2020). The reproduction number of COVID-19 and its correlation with public health interventions. Computational Mechanics, 66(4), 1035-1050. https://doi.org/10.1007/s00466-020-01880-8

Liu, P., Chen, W., \& Chen, J. P. (2019). Viral metagenomics revealed Sendai virus and coronavirus infection of Malayan pangolins (Manis javanica). $\quad$ Viruses, $11(11), \quad 979$. https://doi.org/10.3390/v11110979

Liu, Y., Gayle, A. A., Wilder-Smith, A., \& Rocklöv, J. (2020). The reproductive number of COVID-19 is higher compared to SARS coronavirus. Journal of travel medicine. https://doi.org/10.1093/jtm/taaa021

Lovato, A., \& De Filippis, C. (2020). Clinical presentation of COVID-19: a systematic review focusing on upper airway symptoms. Ear, Nose \& Throat Journal, 99(9), 569-576. https://doi.org/10.1177/0145561320920762

Lu, R., Zhao, X., Li, J., Niu, P., Yang, B., Wu, H., ... \& Tan, W. (2020). Genomic characterisation and epidemiology of 2019 novel coronavirus: implications for virus origins and receptor binding. The lancet, 395(10224), 565-574. https://doi.org/10.1016/S0140-6736(20)30251-8

Malik, Y. S., Sircar, S., Bhat, S., Sharun, K., Dhama, K., Dadar, M., ... \& Chaicumpa, W. (2020). Emerging novel coronavirus (2019-nCoV)current scenario, evolutionary perspective based on genome analysis and recent developments. Veterinary quarterly, 40(1), 68-76. https://doi.org/10.1080/01652176.2020.1727993 
Manalo, I. F., Smith, M. K., Cheeley, J., \& Jacobs, R. (2020). A dermatologic manifestation of COVID19: transient livedo reticularis. Journal of the American Academy of Dermatology, 83(2), 700. https://doi.org/10.1016/j.jaad.2020.05.001

Mao, L., Jin, H., Wang, M., Hu, Y., Chen, S., He, Q., ... \& Hu, B. (2020). Neurologic manifestations of hospitalized patients with coronavirus disease 2019 in Wuhan, China. JAMA neurology, 77(6), 683-690. https://doi.org/10.1001/jamaneurol.2020.1127

Maqbool, A., \& Khan, N. Z. (2020). Analyzing barriers for implementation of public health and social measures to prevent the transmission of COVID-19 disease using DEMATEL method. Diabetes \& Metabolic Syndrome: Clinical Research \& Reviews, 14(5), 887-892. https://doi.org/10.1016/j.dsx.2020.06.024

Marzano, A. V., Genovese, G., Fabbrocini, G., Pigatto, P., Monfrecola, G., Piraccini, B. M., ... \& CalzavaraPinton, P. (2020). Varicella-like exanthem as a specific COVID-19-associated skin manifestation: Multicenter case series of 22 patients. Journal of the American Academy of Dermatology, 83(1), 280-285. https://doi.org/10.1016/j.jaad.2020.04.044

McGonagle, D., O'Donnell, J. S., Sharif, K., Emery, P., \& Bridgewood, C. (2020). Immune mechanisms of pulmonary intravascular coagulopathy in COVID-19 pneumonia. The Lancet Rheumatology. https://doi.org/10.1016/S2665-9913(20)30174-0

Molina, D. K., \& DiMaio, V. J. (2012). Normal organ weights in men: part II-the brain, lungs, liver, spleen and kidneys. The American journal of forensic medicine and pathology, 33(4), 368-372. https://doi.org/10.1097/PAF.0b013e31823d29ad

Molina, D. K., \& DiMaio, V. J. (2015). Normal organ weights in women: part II-the brain, lungs, liver, spleen and kidneys. The American journal of forensic medicine and pathology, 36(3), 182-187. https://doi.org/10.1097/PAF.0000000000000175

Navel, V., Chiambaretta, F., \& Dutheil, F. (2020). Haemorrhagic conjunctivitis with pseudomembranous related to SARS-CoV-2. American journal of ophthalmology case reports, 19, 100735. https://doi.org/10.1016/j.ajoc.2020.100735

Novel, C. P. E. R. E. (2020). The epidemiological characteristics of an outbreak of 2019 novel coronavirus diseases (COVID-19) in China. Zhonghua liu xing bing xue za zhi = Zhonghua liuxingbingxue zazhi, 41(2), 145. https://doi.org/10.46234/ccdcw2020.032

Nuckton, T. J., Alonso, J. A., Kallet, R. H., Daniel, B. M., Pittet, J. F., Eisner, M. D., \& Matthay, M. A. (2002). Pulmonary dead-space fraction as a risk factor for death in the acute respiratory distress syndrome. New England Journal of Medicine, 346(17), 1281-1286. https://doi.org/10.1056/NEJMoa012835
Ogimi, C., Englund, J. A., Bradford, M. C., Qin, X., Boeckh, M., \& Waghmare, A. (2019). Characteristics and outcomes of coronavirus infection in children: the role of viral factors and an immunocompromised state. Journal of the Pediatric Infectious Diseases Society, 8(1), 21-28. https://doi.org/10.1093/jpids/pix093

Organization, W. H. \& Organization, W. H. (2020). Report of the WHO-China joint mission on coronavirus disease 2019 (COVID-19). Geneva.

Oxley, T. J., Mocco, J., Majidi, S., Kellner, C. P., Shoirah, H., Singh, I. P., ... \& Fifi, J. T. (2020). Large-vessel stroke as a presenting feature of Covid-19 in the young. New England Journal of Medicine, 382(20), e60. https://doi.org/10.1056/NEJMc2009787

Pan, C., Chen, L., Lu, C., Zhang, W., Xia, J. A., Sklar, M. C., ... \& Qiu, H. (2020). Lung recruitability in COVID-19-associated acute respiratory distress syndrome: a single-center observational study. American journal of respiratory and critical care medicine, 201(10), 1294-1297. https://doi.org/10.1164/rccm.202003-0527LE

Panciani, P. P., Saraceno, G., Zanin, L., Renisi, G., Signorini, L., Battaglia, L., \& Fontanella, M. M. (2020). SARS-CoV-2:"Three-steps" infection model and CSF diagnostic implication. Brain, behavior and immunity, 87, 128 . https://doi.org/10.1016/j.bbi.2020.05.002

Parrish, C. R., Murcia, P. R., \& Holmes, E. C. (2015). Influenza virus reservoirs and intermediate hosts: dogs, horses and new possibilities for influenza virus exposure of humans. Journal of virology, 89(6), 29902994. https://doi.org/10.1128/JVI.03146-14

Petrosillo, N., Viceconte, G., Ergonul, O., Ippolito, G., \& Petersen, E. (2020). COVID-19, SARS and MERS: are they closely related?. Clinical Microbiology and Infection, 26(6), 729-734. https://doi.org/10.1016/j.cmi.2020.03.026

Posfay-Barbe, K. M., Wagner, N., Gauthey, M., Moussaoui, D., Loevy, N., Diana, A., \& L'Huillier, A. G. (2020). COVID-19 in children and the dynamics of infection in families. Pediatrics, 146(2). https://doi.org/10.1542/peds.2020-1576

Prevention, C. f. D. C. a. (2019). 1918 Pandemic https://www.cdc.gov/flu/pandemic-resources/1918pandemic-h1n1.html

Recalcati, S. (2020). Cutaneous manifestations in COVID-19: a first perspective. Journal of the European Academy of Dermatology and Venereology, 34(5), e212-e213. https://doi.org/10.1111/jdv.16387

Sahetya, S. K., Mancebo, J., \& Brower, R. G. (2017). Fifty years of research in ARDS. Vt selection in acute respiratory distress syndrome. American journal of respiratory and critical care medicine, 196(12), 1519-1525 https://doi.org/10.1164/rccm.201708-1629CI 
Schwierzeck, V., König, J. C., Kühn, J., Mellmann, A., Correa-Martínez, C. L., Omran, H., ... \& Kampmeier, S. (2020). First reported nosocomial outbreak of severe acute respiratory syndrome coronavirus 2 (SARS-CoV-2) in a pediatric dialysis unit. Clinical Infectious Diseases. https://doi.org/10.1093/cid/ciaa491

Seah, I. Y. J. Anderson, D. E., Kang, A. E. Z., Wang, L., Rao, P., Young, B. E., ... \& Agrawal, R. (2020). Assessing viral shedding and infectivity of tears in coronavirus disease 2019 (COVID-19) patients. Ophthalmology, 127(7), 977-979. https://doi.org/10.1016/j.ophtha.2020.03.026

Seah, I., \& Agrawal, R. (2020). Can the coronavirus disease 2019 (COVID-19) affect the eyes? A review of coronaviruses and ocular implications in humans and animals. Ocular immunology and inflammation, 28(3), 391-395. https://doi.org/10.1080/09273948.2020.1738501

Shah, M., Sachdeva, M., \& Dodiuk-Gad, R. P. (2020). COVID-19 and racial disparities. Journal of the American Academy of Dermatology, 83(1), e35. https://doi.org/10.1016/j.jaad.2020.04.046

She, J., Liu, L., \& Liu, W. (2020). COVID-19 epidemic: disease characteristics in children. Journal of medical virology, 92(7), 747-754. https://doi.org/10.1002/jmv.25807

Shi, S., Qin, M., Shen, B., Cai, Y., Liu, T., Yang, F., ... \& Huang, C. (2020). Association of cardiac injury with mortality in hospitalized patients with COVID-19 in Wuhan, China. JAMA cardiology, 5(7), 802-810. https://doi.org/10.1001/jamacardio.2020.0950

Smith, V., Seo, D., Warty, R., Payne, O., Salih, M., Chin, K. L., ... \& Wallace, E. (2020). Maternal and neonatal outcomes associated with COVID-19 infection: A systematic review. Plos one, 15(6), e0234187. https://doi.org/10.1371/journal.pone.0234187

Subramaniam, S., \& Scharrer, I. (2018). Procoagulant activity during viral infections. Front Biosci (Landmark Ed), 23, 1060-1081. https://doi.org/10.2741/4633

Suzuki, M., Saito, K., Min, W. P., Vladau, C., Toida, K., Itoh, H., \& Murakami, S. (2007). Identification of viruses in patients with postviral olfactory dysfunction. The Laryngoscope, 117(2), 272-277. https://doi.org/10.1097/01.mlg.0000249922.37381.1e

Tang, N., Li, D., Wang, X., \& Sun, Z. (2020a). Abnormal coagulation parameters are associated with poor prognosis in patients with novel coronavirus pneumonia. Journal of thrombosis and haemostasis, 18(4), 844-847. https://doi.org/10.1111/jth.14768

Tang, X., Wu, C., Li, X., Song, Y., Yao, X., Wu, X., ... \& $\mathrm{Lu}, \mathrm{J}$. (2020b). On the origin and continuing evolution of SARS-CoV-2. National Science Review, 7(6), 1012-1023. https://doi.org/10.1093/nsr/nwaa036
Tay, M. Z., Poh, C. M., Rénia, L., MacAry, P. A., \& Ng, L. F. (2020). The trinity of COVID-19: immunity, inflammation and intervention. Nature Reviews Immunology, 20(6), 363-374. https://doi.org/10.1038/s41577-020-0311-8

To, K. K. W., Tsang, O. T. Y., Leung, W. S., Tam, A. R., Wu, T. C., Lung, D. C., ... \& Yuen, K. Y. (2020). Temporal profiles of viral load in posterior oropharyngeal saliva samples and serum antibody responses during infection by SARS-CoV-2: an observational cohort study. The Lancet Infectious Diseases, 20(5), 565-574. https://doi.org/10.1016/S1473-3099(20)30196-1

Van Gorp, E. C. M., Suharti, C., Ten Cate, H., Dolmans, W. M. V., van der Meer, J. W., Ten Cate, J. W., \& Brandjes, D. P. M. (1999). Infectious diseases and coagulation disorders. The Journal of infectious diseases, $\quad 180(1), \quad 176-186$. https://doi.org/10.1086/314829

Wan, Y., Shang, J., Graham, R., Baric, R. S., \& Li, F. (2020). Receptor recognition by the novel coronavirus from Wuhan: an analysis based on decade-long structural studies of SARS coronavirus. Journal of virology, 94(7). https://doi.org/10.1128/JVI.00127-20

Wang, D., Hu, B., Hu, C., Zhu, F., Liu, X., Zhang, J., ... \& Peng, Z. (2020). Clinical characteristics of 138 hospitalized patients with 2019 novel coronavirusinfected pneumonia in Wuhan, China. Jama, 323(11), 1061-1069. https://doi.org/10.1001/jama.2020.1585

WHO. (2020a). Breastfeeding advice during the COVID-19 outbreak. World Health Organization. http://www.emro.who.int/nutrition/nutritioninfocus/breastfeeding-advice-during-covid-19outbreak.html

WHO. (2020b). Timeline of WHO's response to COVID-19. https://www.who.int/newsroom/detail/29-06-2020-covidtimeline

Wichmann, D., Sperhake, J. P., Lütgehetmann, M., Steurer, S., Edler, C., Heinemann, A., ... \& Kluge, S. (2020). Autopsy findings and venous thromboembolism in patients with COVID-19: a prospective cohort study. Annals of internal medicine, 173(4), 268-277. https://doi.org/10.7326/M20-2003

Wölfel, R., Corman, V. M., Guggemos, W., Seilmaier, M., Zange, S., Müller, M. A., ... \& Wendtner, C. (2020). Virological assessment of hospitalized patients with COVID-2019. Nature, 581(7809), 465-469. https://doi.org/10.1038/s41586-020-2196-X

Wu, A., Peng, Y., Huang, B., Ding, X., Wang, X., Niu, P., ... \& Jiang, T. (2020a). Genome composition and divergence of the novel coronavirus (2019-nCoV) originating in China. Cell host \& microbe, 27(3), 325-328. https://doi.org/10.1016/j.chom.2020.02.001 
Wu, F., Zhao, S., Yu, B., Chen, Y. M., Wang, W., Song, Z. G., .. \& Zhang, Y. Z. (2020b). A new coronavirus associated with human respiratory disease in China. Nature, 579(7798), 265-269. https://doi.org/10.1038/s41586-020-2008-3

Wu, P., Duan, F., Luo, C., Liu, Q., Qu, X., Liang, L., \& Wu, K. (2020c). Characteristics of ocular findings of patients with coronavirus disease 2019 (COVID-19) in Hubei Province, China. JAMA ophthalmology, 138(5), 575-578. https://doi.org/10.1001/jamaophthalmol.2020.1291

Wu, Z., \& McGoogan, J. M. (2020). Characteristics of and important lessons from the coronavirus disease 2019 (COVID-19) outbreak in China: summary of a report of 72314 cases from the Chinese Center for Disease Control and Prevention. Jama, 323(13), 1239-1242. https://doi.org/10.1001/jama.2020.2648

Xia, J., Tong, J., Liu, M., Shen, Y., \& Guo, D. (2020). Evaluation of coronavirus in tears and conjunctival secretions of patients with SARS-CoV-2 infection. Journal of medical virology, 92(6), 589-594. https://doi.org/10.1002/jmv.25725

Xiao, F., Tang, M., Zheng, X., Liu, Y., Li, X., \& Shan, H. (2020). Evidence for gastrointestinal infection of SARS-CoV-2. Gastroenterology, 158(6), 1831-1833. https://doi.org/10.1053/j.gastro.2020.02.055

Xie, H. T., Jiang, S. Y., Xu, K. K., Liu, X., Xu, B., Wang, L., \& Zhang, M. C. (2020a). SARS-CoV-2 in the ocular surface of COVID-19 patients. Eye and Vision, 7(1), 1-3. https://doi.org/10.1186/s40662-020-00189-0
Xie, Y., Wang, X., Yang, P., \& Zhang, S. (2020b). COVID19 complicated by acute pulmonary embolism. Radiology: Cardiothoracic Imaging, 2(2), e200067. https://doi.org/10.1148/ryct.2020200067

Ye, M., Ren, Y., \& Lv, T. (2020). Encephalitis as a clinical manifestation of COVID-19. Brain, behavior and immunity. https://doi.org/10.1016/j.bbi.2020.04.017

Zhang, T., Wu, Q., \& Zhang, Z. (2020a). Probable pangolin origin of SARS-CoV-2 associated with the COVID-19 outbreak. Current biology, 30(7), 1346-1351. https://doi.org/10.1016/j.cub.2020.03.022

Zhang, Y., Xiao, M., Zhang, S., Xia, P., Cao, W., Jiang, W., ... \& Zhang, S. (2020b). Coagulopathy and antiphospholipid antibodies in patients with Covid19. New England Journal of Medicine, 382(17), e38. https://doi.org/10.1056/NEJMc2007575

Zhou, F., Yu, T., Du, R., Fan, G., Liu, Y., Liu, Z., ... \& Cao, B. (2020a). Clinical course and risk factors for mortality of adult inpatients with COVID-19 in Wuhan, China: a retrospective cohort study. The lancet, 395(10229), 1054-1062. https://doi.org/10.1016/S0140-6736(20)30566-3

Zhou, P., Yang, X. L., Wang, X. G., Hu, B., Zhang, L., Zhang, W., ... \& Shi, Z. L. (2020b). A pneumonia outbreak associated with a new coronavirus of probable bat origin. nature, 579(7798), 270-273. https://doi.org/10.1038/s41586-020-2012-7

Zhu, N., Zhang, D., Wang, W., Li, X., Yang, B., Song, J., ... \& Tan, W. (2020). A novel coronavirus from patients with pneumonia in China, 2019. New England journal of medicine. https://doi.org/10.1056/NEJMoa2001017 